\title{
Pengaruh Susu Fortifikasi Besi-Zink Terhadap Tingkat Kesegaran Jasmani Anak Usia 7-9 Tahun di Sekolah Dasar Surakarta
}

\author{
Endang Dewi Lestari, Zustäin Noor Adhim, Harsono Salimo, Mustarsid \\ Bagian Ilmu Kesehatan Anak FK Universitas Sebelas Maret RSUD Moewardi Surakarta
}

Latar belakang. Defisiensi zat gizi mikro merupakan masalah kesehatan di negara berkembang. Besi dan zink merupakan zat gizi mikro yang esensial untuk tubuh. Kekurangan dua jenis zat gizi mikro ini akan menyebabkan kelainan pertumbuhan dan perkembangan yang berpengaruh terhadap tingkat kesegaran jasmani.

Tujuan. Mengetahui pengaruh susu fortifikasi besi-zink terhadap tingkat kesegaran jasmani anak usia 7-9 tahun di Sekolah Dasar Surakarta

Metode. Penelitian uji klinis acak kasus-kontrol dilakukan pada 220 anak gizi kurang, 114 anak mendapat susu yang mengandung iron pyrophosphate $(12.15 \mathrm{mg}$ ) and zinc sulfate $(4.4 \mathrm{mg}), 106$ sebagai kelompok kontrol. Kesegaran jasmani diukur dengan menggunakan modified-Harvard step test. Analisis statistik menggunakan SPSS versi 16.0.

Hasil. Rata-rata modified-Harvard step test score pada kelompok studi saat awal penelitian 10.829.32 $(\mathrm{SD} \pm 6.803 .15)$, dan pada kelompok kontrol $6.407 .06(\mathrm{SD} \pm 3.220 .03)$. Setelah 6 bulan pemberian suplementasi, rata-rata modified-Harvard step test score pada kelompok perlakuan naik menjadi 27.037.92 $\left(\mathrm{SD}_{ \pm}\right.$5.757.64) dan pada kelompok kontrol naik menjadi 21.5333.14 ( $\mathrm{SD}_{ \pm}$7.176.76). Terdapat perbedaan peningkatan modified-Harvard step test score sebesar 4388.9 points pada kelompok perlakuan $(p=<0.001$; $95 \%$ CI 2548.3-6229.6).

Kesimpulan. Pemberian susu fortifikasi besi-zink berpengaruh terhadap peningkatan tingkat kesegaran jasmani secara bermakna. (Sari Pediatri 2010;12(2):92-8).

Kata kunci: besi dan zink, gizi kurang, kesegaran jasmani, anak

$\mathrm{M}$ asalah defisiensi zat gizi mikro seperti defisiensi zink dan besi merupakan masalah kesehatan masyarakat di banyak negara berkembang. ${ }^{1}$ Masalah

Alamat korespondensi:

Dr. Endang Dewi Lestari, Sp.A(K). Staf UPF. Anak. Bag.IKA RSUD Dr. Moewardi Jl. Kol Sutarto 132 Solo Jawa Tengah. TeLp. 0271- 666866 kekurangan gizi pada umumnya disebabkan oleh kemiskinan, kekurangan persediaan pangan, kualitas hidup (sanitasi) yang kurang baik, kesadaran masyarakat akan pengetahuan gizi kurang, dan terdapat daerah miskin gizi. Tingkat sosial ekonomi yang rendah menyebabkan daya beli masyarakat turun terhadap bahan makanan dengan kandungan besi dan zink yang tinggi, seperti protein hewani. ${ }^{2,3}$ 
Zink dan besi merupakan mikronutrein esensial untuk pertumbuhan dan perkembangan tubuh serta sistem imun manusia. ${ }^{4,5}$ Defisiensi mikronutrien tersebut menyebabkan penurunan sistem imun, gangguan perkembangan psikomotor dan menurunkan kemampuan kerja. Hal tersebut akan berpengaruh terhadap tingkat kesegaran jasmani, ${ }^{6,7}$ yang sangat penting dalam tercapainya perkembangan dan pertumbuhan optimal pada masa anak-anak. ${ }^{4,5}$

Berbagai cara telah dilakukan untuk menanggulangi masalah defisiensi gizi seperti penyuluhan gizi, pemberian bantuan pangan, suplementasi gizi, diversifikasi pangan dan fortifikasi pangan. Pemberian suplementasi mikronutrien zink dan besi merupakan suatu alternatif untuk memenuhi kebutuhan yang tidak dapat dipenuhi dari asupan makanan sehari-hari. ${ }^{8,9}$ Susu fortifikasi merupakan media yang menarik untuk meningkatkan asupan zat gizi mikronutrien besi-zink dalam populasi masyarakat. ${ }^{10}$ Perlu adanya penelitian untuk mengetahui efektivitas susu yang difortifikasi besi-zink terhadap kesegaran jasmani.

\section{Metode}

Telah dilakukan penelitian uji klinis (randomized controll trial) terhadap murid sekolah dasar. Sepuluh sekolah dasar (SD) di Surakarta, yaitu SD Purwoprajan, SD Balapan, SD Joyontakan, SD Sawahan 2, SD Purwotomo, SD Sumber 5, SD Krajan, SD Debegan, SD Bumi 2, dan SD Begalon 2 antara Juli 2007-Januari 2008. Populasi target pada penelitian ini adalah semua anak gizi kurang di SD Surakarta. Populasi terjangkau adalah anak dengan gizi kurang berusia 7-9 tahun di SD Surakarta. Pengambilan sampel penelitian dilakukan secara purposive sampling anak di sekolah dasar miskin Surakarta. Kriteria inklusi anak usia 7-9 tahun, murid SD dengan orang tua mempunyai tingkat

\section{Alur Penelitian}

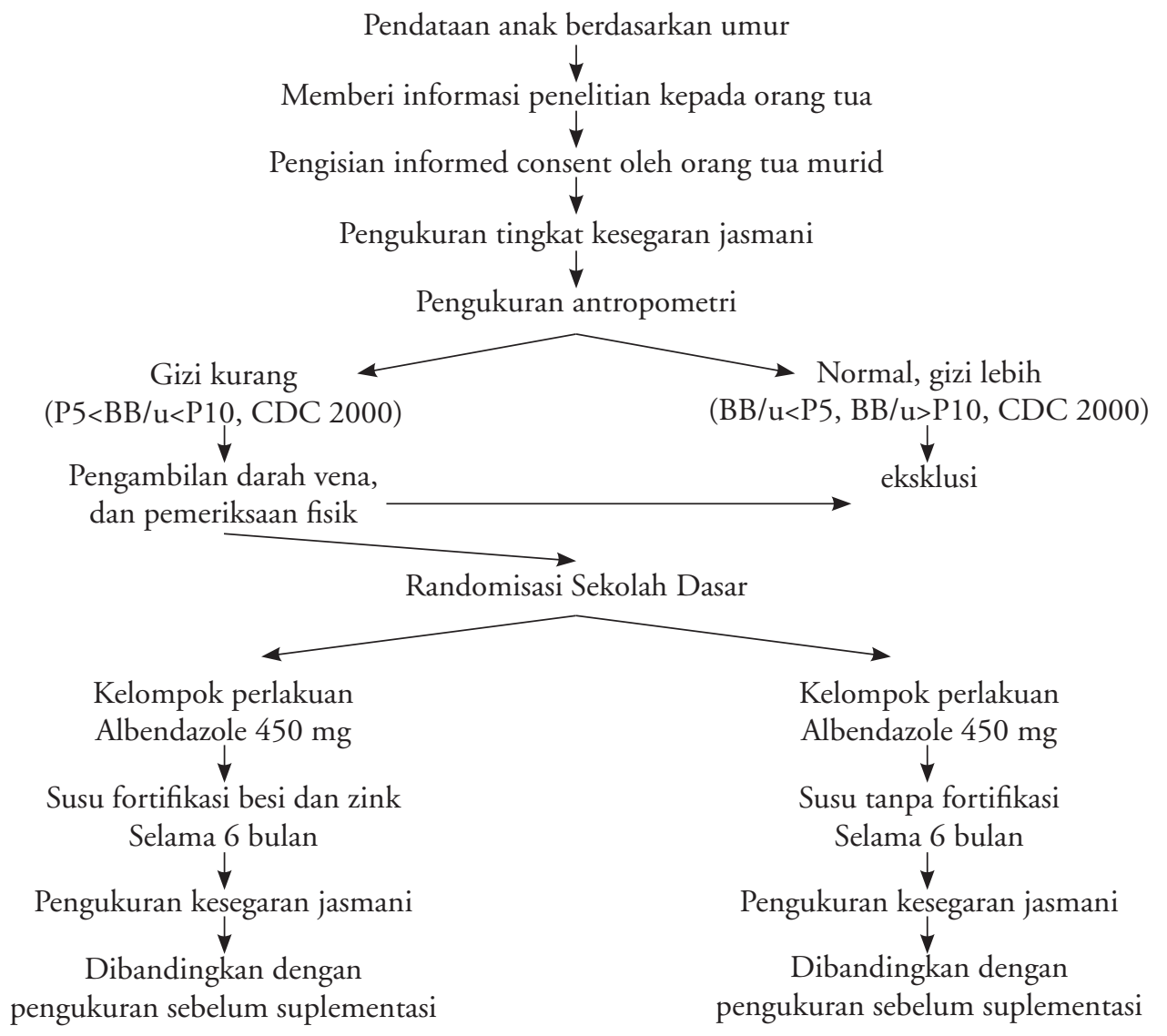

Pendataan anak berdasarkan umur

Memberi informasi penelitian kepada orang tua

Pengisian informed consent oleh orang tua murid

Pengukuran tingkat kesegaran jasmani

Pengukuran antropometri

Sari Pediatri, Vol. 12, No. 2, Agustus 2010 
pendapatan rendah yaitu kurang atau sama dengan Rp. 25.000/hari, gizi kurang $\left(\mathrm{P}^{5}<\mathrm{BB} / \mathrm{u}<\mathrm{P}^{10}, \mathrm{CDC}\right.$ 2000), tidak dalam keadaan sakit atau dalam tahap penyembuhan dari sakit, tidak merokok dan orang tua memahami informasi penelitian dan menandatangani informed consent. Kriteria eksklusi anak dengan kadar hemoglobin kurang dari $8 \mathrm{gr} / \mathrm{dl}$, anak yang pada saat dilaksanakan penelitian tidak masuk sekolah, atau anak tidak berada di tempat atau lokasi penelitian.

\section{Susu yang difortifikasi besi dan zink}

Pada kelompok perlakuan diberikan susu satu bungkus yang dilarutkan dalam air $200 \mathrm{cc}$ mengandung 12,15 mg iron phyrophosphate dan 4,4 mg zinc sulfate pada pagi hari dan sore hari, sedangkan pada kelompok kontrol diberikan susu dengan kandungan $0,47 \mathrm{mg}$ iron phyrophosphate dan 1,63 mg zinc sulfate. Susu diberikan dua kali sehari pada pagi dan sore hari. Pada pagi hari anak-anak minum susu bersama-sama diawasi oleh guru wali kelas di dalam kelas, sedangkan pada sore hari diawasi oleh orang tua di rumah masingmasing. Susu fortifikasi diberikan selama enam bulan. Guru dan orang tua murid di rumah menuliskan catatan harian tentang susu yang diberikan.

\section{Kesegaran Jasmani}

Dipergunakan alat ukur modified-Harvard Step Test, menggunakan bangku untuk mengukur kemampuan daya tahan sistem jantung dan paru seseorang. Bangku yang digunakan memiliki ukuran lebar $42 \mathrm{~cm}$, panjang $38 \mathrm{~cm}$ dan ketinggian $30 \mathrm{~cm}$. Uji kesegaran jasmani dilakukan di sekolah setempat dengan cara sebagai berikut, dihitung frekuensi denyut nadi istirahat, dalam posisi badan tegak, siswa diminta memakai tas ransel berisi gula dengan berat $20 \%$ dari berat badan anak, siswa disuruh naik turun bangku dengan frekuensi 30 kali per menit secara teratur, tes dihentikan apabila irama naik turun tidak sesuai dengan metronom sebanyak tiga kali, dan setelah selesai siswa duduk dan dihitung denyut nadinya pada pergelangan tangan (arteria radialis) selama 30 detik pada menit ke 1, 2, dan 3.

Skor dihitung dengan cara lama step test (detik) $\mathrm{x}$ $100+\left(\mathrm{HR}_{1}+\mathrm{HR}_{2}+\mathrm{HR}_{3}\right) \cdot{ }^{11}$

Data yang didapat diolah menggunakan SPSS 16.0. Untuk variabel usia dan berat badan akan dicari nilai rata-ratanya. Perbandingan kedua variabel tersebut pada masing-masing kelompok akan menggunakan $X^{2}$ untuk data kategorikal, sedangkan untuk data yang numerikal akan menggunakan independent sample $T$ test. Pada masing-masing kelompok, hasil pengukuran tingkat kesegaran jasmani dengan modified-Havard step test baik sebelum maupun sesudah suplementasi akan dicari nilai rata-ratanya. Pengaruh pemberian susu yang difortifikasi besi-zink menggunakan analisis linier ganda.

\section{Hasil}

Penelitian uji klinis acak terkontrol dilakukan selama periode bulan Juli 2007 sampai dengan Januari 2008 pada 220 anak usia 7-9 tahun yang memenuhi kriteria inklusi dan eksklusi penelitian. Karakteristik dasar subyek penelitian tertera pada Tabel 1 .

Jumlah subyek pada kelompok besi dan zink 114 anak, 62 anak laki-laki $(54,4 \%)$ dan 52 anak perempuan $(45,6 \%)$ dan pada kelompok kontrol 106 anak. terdiri dari 53 anak laki-laki (50,0\%) dan 53 anak perempuan (50,0\%). Berat badan rata-rata pada kelompok besi dan zink 19,17 $\mathrm{kg}(\mathrm{SD} \pm 1,6)$ dibandingkan pada kelompok kontrol 18,98 $\mathrm{kg}(\mathrm{SD} \pm 1,8)(p=0,41)$.

Tabel 2 menunjukkan hasil modified-Harvard step test fitness score yang dilakukan pada awal penelitian. Persentil ke-50 modified-Harvard step test score 7005,0. Persentil ke 50 lama modified-Harvard step test 67,00 detik.

Pada awal penelitian rata-rata modified-Harvard step test score antara kelompok besi dan zink dengan kelompok kontrol berbeda secara signifikan $\left(10829.3 \pm 637.2\right.$ vs $6407.1 \pm 312.8{ }^{`} ; p=<0.001$ \{CI 95\%:2990.55-5853.97\}). Skor terendah pada kelompok besi dan zink adalah 3460 sedangkan pada kelompok kontrol 1976. Skor tertinggi pada kelompok besi dan zink 30416 dan pada kelompok

Tabel 1. Karakteristik subyek penelitian

\begin{tabular}{lcc}
\hline Karakteristik & $\begin{array}{c}\text { Besi dan zink } \\
\mathrm{n}=114\end{array}$ & $\begin{array}{c}\text { Kontrol } \\
\mathrm{n}=106\end{array}$ \\
\hline Jenis kelamin (\%) & & \\
$\quad$ Laki-laki & $62(54,4)$ & $53(50,0)$ \\
$\quad$ Perempuan & $52(45,6)$ & $53(50,0)$ \\
Berat badan (rata \pm SD) $\mathrm{kg}$ & $19,17 \pm 1,6$ & $18,98 \pm 1,8$ \\
\hline
\end{tabular}

*Independent sample t-test 
perlakuan adalah 21412. Pada kelompok besi dan zink terdapat 39 (34.2\%) anak dengan modified-Harvard step test score dibawah persentil ke 50 (dibawah 7005.00), sedangkan pada kelompok kontrol terdapat $71(67.0 \%)$ anak dengan modified-Harvard step test score dibawah persentil ke 50 (dibawah 7005.00). Lama rata-rata step test antara kelompok besi dan zink dengan kelompok kontrol berbeda secara signifikan $(103.63 \pm 66.65$ vs $60.29 \pm 32.2376$; $p=<0.001$ \{CI 95\%:29.25-57.42\}). Jumlah subyek yang menyelesaikan penelitian sampai akhir 217 anak. Tiga orang anak pindah sekolah pada pertengahan penelitian, dua orang pada kelompok besi dan zink dan satu orang pada kelompok kontrol.

Nilai rata-rata modified-Harvard step test score pada awal penelitian lebih tinggi pada kelompok besi dan zink $10829.3( \pm 637.2)$ dibandingkan pada kelompok kontrol $6407.1( \pm 312.8)(p<0.001)$. Setelah tiga bulan pemberian susu fortifikasi besi dan zink nilai rata-rata modified-Harvard step test score pada kelompok besi dan zink lebih tinggi dibandingkan pada kelompok kontrol $(17728.9 \pm 634.0 \mathrm{vs} 12242.5 \pm 461.2 ; p<0.001)$. Pada akhir penelitian nilai rata-rata modified-Harvard step test score pada kelompok besi dan zink juga lebih tinggi dibandingkan pada kelompok kontrol (27037.9 \pm 544.0vs21533.1 $\pm 700.4 ; p<0.001$ ).

Pada awal penelitian sebanyak 39 anak (34.2\%) dari kelompok besi dan zink modified-Harvard step test score berada di bawah persentil ke-50, sedangkan pada kelompok kontrol sebanyak 71 anak (67.0\%). Setelah 3 bulan pemberian suplementasi susu, semua anak pada kelompok besi dan zink telah melewati persentil ke-50 dari modified-Harvard step test score dan sebanyak 9 anak $(8.5 \%)$ dari kelompok kontrol masih berada di bawah persentil ke-50. Diakhir penelitian terdapat masing-masing satu anak yang modifiedHarvard step test score-nya berada di bawah persentil ke-50 dikarenakan tidak mengikuti tes kesegaran jasmani. Dari Gambar 2 terlihat bahwa pada kedua kelompok mengalami peningkatan modified-Harvard step test score.

Berdasarkan analisis regresi liner ganda, setelah bulan ke-3 pemberian susu didapatkan bahwa susu yang difortifikasi besi-zink meningkatkan kesegaran jasmani dengan nilai modified Harvard step test score 2768,9 lebih tinggi dibandingkan dengan susu kontrol $(p=<0,001$; 95\%CI7169,7-9609,9) (Tabel 3). Dari Gambar 3. terlihat bahwa pada kedua kelompok mengalami peningkatan modified Harvard step test score.

Berdasarkan analisis regresi liner ganda, setelah bulan ke-6 pemberian susu didapatkan bahwa susu yang difortifikasi besi-zink meningkatkan kesegaran jasmani dengan nilai modified Harvard step test score 4388.9 lebih tinggi dibandingkan dengan susu kontrol ( $p=<0.001$; 95\% CI 2548.3-6229.6) (Tabel. 3).

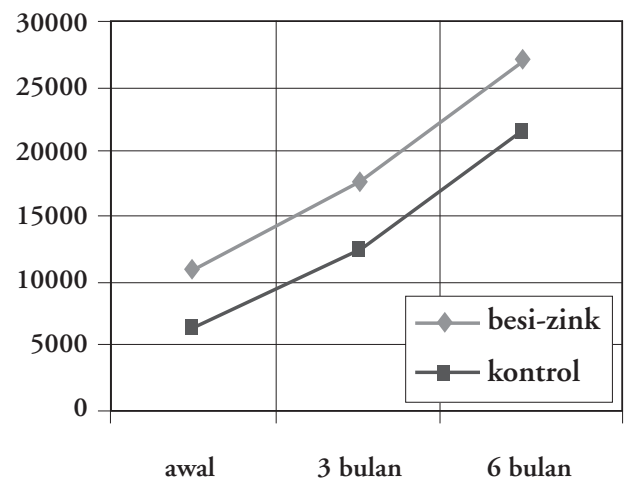

Gambar 1. Grafik peningkatan modified-harvard step test score

Tabel 2. Skor modified-Harvard step dan lama step test

\begin{tabular}{lccc}
\hline Modified-Harvard step test score & Besi dan zink & Kontrol & P \\
\hline Sebelum supplementasi & & & \\
Rata-rata step test score $( \pm$ SD) & $10829.3 \pm 637.2$ & $6407.1 \pm 312.8$ & $<0.001^{*}$ \\
Skor minimal & 3640.0 & 1976.0 & \\
Skor maksimal & 30416.0 & 21412.0 & \\
Step test score $(<\mathrm{P}$ 50th) (\%) & $39(34.2)$ & $71(67.0)$ & \\
Lama rata-rata step test $( \pm$ SD) & $103.63 \pm 66.65$ & $60.29 \pm 32.23$ & $<0.001^{*}$ \\
Skor minimal & 33.00 & 16.00 & \\
Skor maksimal & 300.00 & 210.00 & \\
Lama step test $(<\mathrm{P}$ 50th) $(\%)$ & $41(36.0)$ & $71(67.0)$ & \\
\hline
\end{tabular}

${ }^{*}$ Independent sample t-test 


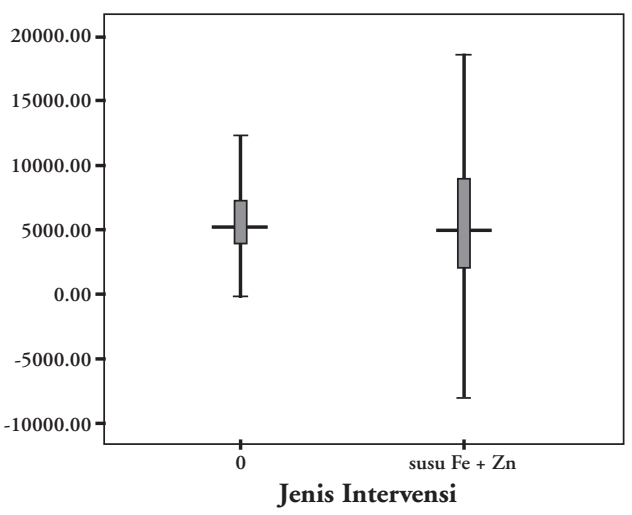

Gambar 2. Perbedaan selisih peningkatan modified-Harvard step test score sebelum dan setelah 3 bulan pemberian susu yang difortifikasi besi-zink

\section{Pembahasan}

Penelitian uji klinis acak di sekolah dasar di daerah masyarakat ekonomi rendah di Solo, dengan menggunakan data dari Dinas Pendidikan Nasional Surakarta. Subyek yang diambil adalah anak dengan status gizi kurang dan tingkat ekonomi yang rendah. Pemilihan subyek ini dimaksudkan untuk mencari subyek yang mengalami kekurangan mikronutrien besi dan zink yang banyak terjadi pada anak dengan status gizi kurang dan tingkat ekonomi rendah. Sehingga subyek yang didapat mempunyai karakteristik dasar yang serupa seperti dalam hal konsumsi makanan sehari-hari, diharapkan dapat menyetarakan jumlah asupan besi dan zink di luar intervensi. Pemilihan subyek dengan mengeksklusi anak dengan kadar

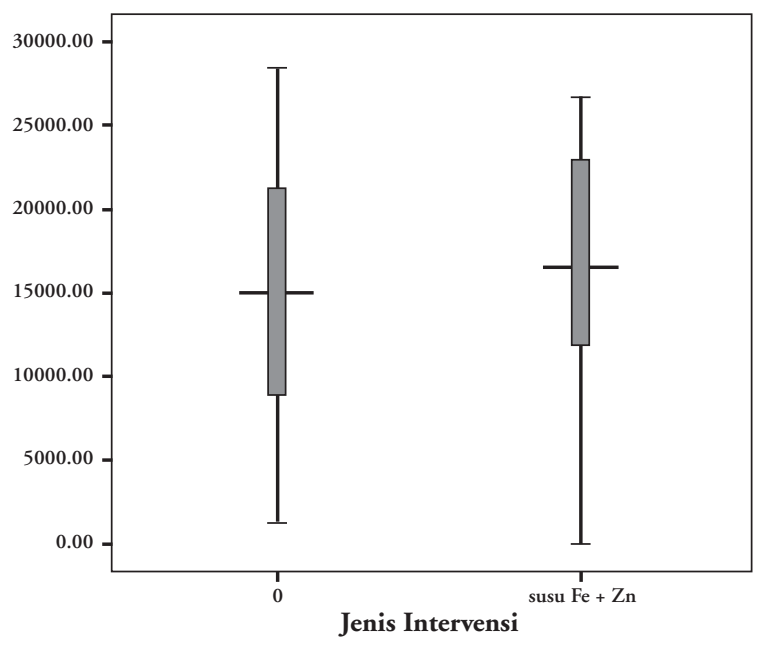

Gambar 3. Perbedaan selisih peningkatan modified Harvard step test score sebelum dan setelah 6 bulan pemberian susu yang difortifikasi besi-zink

hemoglobin kurang dari $8 \mathrm{~g} / \mathrm{dl}$ dimaksudkan untuk menyetarakan kadar besi pada subyek.

Pemberian suplementasi kombinasi besi dan zink dalam bentuk cair pada beberapa penelitian sebelumnya terbukti tidak bermanfaat dibandingkan pemberian besi dan zink secara terpisah dalam bentuk cair. Suplementasi besi dan zink dalam bentuk cair tidak mempunyai efek efikasi dan tidak dapat meningkatkan kadar zat besi dan zink di dalam darah. Hal ini disebabkan oleh karena terjadinya kompetisi pada saat penyerapan besi dan zink di dalam usus halus. Kompetisi ini tidak terjadi apabila pemberian besi dan zink di lakukan dalam bentuk makanan padat dan perbandingan besi dan zink tidak melebihi

Tabel 3. Analisis regresi linier ganda tentang pengaruh fortifikasi besi-zink pada susu terhadap tingkat kesegaran jasmani pada bulan ke-3 dan ke-6*

\begin{tabular}{lcccc}
\hline \multirow{2}{*}{ Variabel } & Koefisien & \multicolumn{2}{c}{$95 \%$ CI } & \multirow{2}{*}{$\mathrm{p}$} \\
\cline { 3 - 4 } & $(\beta)$ & Batas bawah & Batas atas & \\
\hline Intervensi susu besi-zink & 2796.9 & 1380.8 & 4213.1 & $<0.001$ \\
Step test sebelum & 0.6 & 0.5 & 0.7 & $<0.001$ \\
Konstanta & 8338.3 & 7169.7 & 9606.9 & $<0.001$ \\
\hline N observasi = 217, Adj R2 $=42,9 \%, \mathrm{p}=<0.001$ & & & \\
\hline Intervensi susu besi-zink & 4388.9 & 2548.3 & 6229.6 & $<0.001$ \\
Step test sebelum & 0.3 & 0.1 & 0.4 & 0.002 \\
Konstanta & 19932.6 & 8348.6 & 21516.5 & $<0.001$ \\
\hline
\end{tabular}

$\mathrm{N}$ observasi $=217$, Adj $\mathrm{R} 2=18,3 \%, \mathrm{p}=<0.001$

*modified Harvard step test score 
rasio 3:1. ${ }^{12}$ Pada penelitian ini fortifikasi besi dan zink dilakukan dalam 100 gram susu satu sachet yang dilarutkan dalam air 200 cc yang mengandung 12.15 mg iron phyrophosphate dan $4.4 \mathrm{mg}$ zink sulfate (rasio $3: 1$ ), sedangkan pada kelompok kontrol diberikan susu dengan kandungan $0.47 \mathrm{mg}$ iron phyrophosphate dan $1.63 \mathrm{mg}$ zink sulfate.

Zat besi diperlukan untuk sintesis hemoglobin dan mioglobin yang menentukan banyak sedikitnya $\mathrm{O}_{2}$ yang dibebaskan. Hasil akhir dari proses oksidasi ini berupa ATP. ${ }^{1}$ Defisiensi besi menyebabkan berkurangnya kemampuan tubuh untuk beraktivitas secara baik. Hal ini akan menurunkan tingkat kesegaran jasmani. Jika kondisi ini berlangsung terus sebagai akibat pemasukan zat besi yang tidak mencukupi kebutuhan, dapat memberikan dampak buruk terhadap kesehatan baik secara mental dan juga fisik. ${ }^{8,13}$

Zink berperan sebagai katalisatsor enzim karbonik anhidrase yang diperlukan tubuh untuk mengkatalisis proses $\mathrm{CO}_{2}+\mathrm{H}_{2} \mathrm{O}$ menjadi $\mathrm{HCO}_{3}^{-}+\mathrm{H}^{+}$dan proses sebaliknya. Proses metabolisme sel akan menghasilkan $\mathrm{CO}_{2}$ sebagai salah satu hasil akhir. Saat tubuh beraktivitas atau melakukan latihan fisik yang terus-menerus dan berlangsung lama, akan terjadi peningkatan $\mathrm{CO}_{2}$. Peningkatan kadar $\mathrm{CO}_{2}$ dalam darah akan mengakibatkan ikatan hemoglobin terhadap $\mathrm{O}_{2}$ berkurang. ${ }^{14,15}$ Tubuh memerlukan $\mathrm{O}_{2}$ yang cukup untuk dapat melakukan aktivitas fisik yang optimal. ${ }^{16,17}$ Individu yang kekurangan zat gizi mikronutrien besi dan zink mempunyai kemampuan bekerja lebih rendah dibandingkan dengan yang cukup gizi, dan kemampuannya akan berkurang dengan habisnya cadangan makanan selama melangsungkan suatu kegiatan. ${ }^{13}$ Proses aktivitas fisik akan menjadi lebih baik dengan kandungan zat besi dan zink yang mencukupi kebutuhan yang diperlukan oleh tubuh. ${ }^{18}$

Hasil utama penelitian menunjukkan bahwa suplementasi susu yang difortifikasi besi-zink meningkatkan kesegaran jasmani secara bermakna. Berdasarkan analisis regresi linier ganda susu yang difortifikasi besi-zink memberikan pengaruh yang signifikan terhadap modified-Harvard step test score dengan nilai koeffisien sebesar $4388.9(p=<0.001$, $95 \%$ CI 2548.3 - 6229.6). Hal ini dapat diartikan bahwa susu yang telah difortifikasi besi-zink mampu meningkatkan modified-Harvard step test score 4388,9 poin lebih tinggi dibandingkan dengan susu yang tidak difortifikasi besi-zink.
Randomisasi pada penelitian dilakukan pada Sekolah Dasar, untuk memudahkan dalam memberikan jenis susu kepada subyek penelitian. Jika randomisasi dilakukan terhadap subyek penelitian maka dalam satu sekolah terdapat dua kelompok subyek dengan dua jenis susu, dikhawatirkan akan mengganggu penelitian dan berakibat terhadap modified-Harvard step test score pada awal penelitian. Terdapat perbedaan yang bermakna rata-rata modifiedHarvard step test antara kelompok yang mendapat susu yang difortfikasi besi-zink dan kelompok kontrol. Upaya telah dilakukan untuk menyamakan faktorfaktor lain yang mempengaruhi kesegaran jasmani, namun hal ini masih merupakan kelemahan dari penelitian ini.

\section{Kesimpulan}

Disimpulkan bahwa suplementasi susu yang difortifikasi besi-zink selama enam bulan meningkatkan kesegaran jasmani anak dengan gizi kurang secara bermakna.

\section{Ucapan terima kasih}

Ucapan terimakasih kami ucapkan kepada para siswa dan orang tuanya yang telah merelakan diri untuk ikut serta dalam penelitian ini sampai akhir. Ucapan terimakasih juga kami sampaikan kepada PT NESTLE Indonesia yang telah memberikan sponsor didalam pelaksanaan penelitian ini. Terimakasih kami ucapkan kepada Dr. Leilani Lestarina, Dr. Tati Bardosono, PhD dan Prof. Dr. Bhisma Murti, PhD, MPH, MSc yang telah berkontribusi didalam pelaksanaan penelitian, metodologi maupun pengolahan statistik.

\section{Daftar pustaka}

1. Wieringa FT, Berger J, Djikhuizen MA, Hidayat A, Ningh NX, Utomo B, Wasantwisut E, Winichagoon P. Combined iron and zinc suplementation in infants improves iron and zinc status but interactions reduced efficacy in a multicountry trial in Southeast Asia. J nutr 2007;7; 466-71.

2. Bhutta ZA. Iron and zinc deficiency in children in developing countries. British Med J 2007;334; 104-5.

3. Prasad AS. Zinc deficiency. British Med J 2003; 326: 409-10.

4. Lestari ED, Salimo H, Bardosono S, Lestarina L. Effect 
of iron-zinc fortified milk on iron status and functional outcomes in underweight children. Paediatr Indones 2009; 49: 139-148.

5. Lestari ED, Salimo H, Lilisianawati, Hadianto DM, Sari MGK. Association between C-reactive protein levels and physical in 7 to 9 year old children at poor elementary schools in Surakarta, Indonesia. Paediatr Indones 2009; 49: 75-81.

6. Gera T, Scahdev HPS, Nestel P. Effect of Iron Suplementation on Physical Performance in Children and Adolescents : Systematic Review of Randomized Controlled Trials. Indian Pediatrics 2007; 44; 15-24.

7. Penny ME, Marin RM, Duran A, Peerson JM, Lanata CF, Lonnerdal B, Black RE, Brown KH. Randomized controlled trial of the effect of daily supplementation with zinc or multiple micronutrients on the morbidity, growth and micronutrient status of young Peruvian children. Am J Clin Nutr 2004;79; 457-65.

8. Nasution E. Efek suplementasi zink dan besi pada pertumbuhan anak. USU digital library. 2004.

9. Siagian A. Pendekatan fortifikasi pangan untuk mengatasi masalah kekurangan zat gizi mikro. USU digital library. 2004.

10. Villalpando S, Shamah T, Rivera JA, Lara Y, Monterrubio E. Fortifying milk with ferrous gluconate and zink oxide in a public nutrition program reduced the prevalence of anemia in Toddler. Am J Clin Nut 2006; 136; 2633-7.

11. Stephenson LS, Latham MC. Physical fitness, growth and appetite of Kenyan school boys with Hookworm, Trichuris trichuria, Ascaris lumbriciodes infections are improved four months after a single dose of albendazole. J Nutr 1993;193; 1036-46.

12. Etcheverry P, Hawthorne KM, Liang LK, Abrams SA, Griffin IJ. Effect of beef and soy proteins on the absorptions of non-heme iron and inorganic zinc in children. J Am Coll Nutr 2006; 25; 34-40.

13. Suniar L. Dukungan zat gizi untuk menunjang prestasi olahraga. Jakarta. 2002.

14. Breton $S$. The celluler physiology of carbonic anhidrase. J Pancreas 2001; 24; 159-64.

15. Geers C, Gros G. Carbon dioxide transport and carbonic anhydrase in blood and muscle. Am Physiol Soc 2000; 80; 681-707.

16. Harold W, Kohl III, Hobbs KE. Development of physical activity behaviors of children and adolescents. Pediatrics 1998; 101; 549-54.

17. Lutan R. Menuju sehat dan bugar. Direktorat Jenderal Pendidikan Dasar dan Menengah. Jakarta: 2002.

18. Arifin Z. Beberapa unsur mineral esensial mikro dalam sistem biologi dan metode analisisnya. Jurnal Litbang Pertanian 2008; 27; 99-105. 